\title{
Review
}

Journal of Innate

Immunity
J Innate Immun 2009;1:4-17

DOI: $\underline{10.1159 / 000141865}$
Received: March 28, 2008

Accepted after revision: April 30, 2008

Published online: June 25, 2008

\section{The Role of Epithelial Integrin Receptors in Recognition of Pulmonary Pathogens}

\author{
Marina Ulanova Sean Gravelle Rebecca Barnes \\ Northern Ontario School of Medicine, Lakehead University, Thunder Bay, Ont., Canada
}

\begin{abstract}
Key Words
Integrins · Lung • Epithelial cells · Innate Immunity •

Pattern recognition receptors $\cdot$ Host-pathogen interactions
\end{abstract}

\begin{abstract}
Integrins are a large family of heterodimeric transmembrane cell adhesion receptors. During the last decade, it has become clear that integrins significantly participate in various host-pathogen interactions involving pathogenic bacteria, fungi, and viruses. Many bacteria possess adhesins that can bind either directly or indirectly to integrins. However, there appears to be an emerging role for integrins beyond simply adhesion molecules. Given the conserved nature of integrin structure and function, and the diversity of the pathogens which use integrins, it appears that they may act as pattern recognition receptors important for the innate immune response. Several clinically significant bacterial pathogens target lung epithelial integrins, and this review will focus on exploring various structures and mechanisms involved in these interactions.

Copyright $\odot 2008$ S. Karger AG, Basel
\end{abstract}

\section{Introduction}

Integrins are a large family of $\alpha \beta$ heterodimeric transmembrane receptors that interact with components of the extracellular matrix (ECM) and some cell-surface receptors. In humans there are $18 \alpha$ and $8 \beta$ subunits which form 24 different heterodimers [reviewed by 1]. Large extracellular domains of integrins mediate interactions with extracellular ligands, while the cytoplasmic domains mediate communications with the cytoskeleton and signaling molecules [reviewed by 2]. Based on the crystal structure resolution of the $\alpha \mathrm{v} \beta 3$ integrin extracellular domain, ligand recognition is mainly mediated by a cationic binding site on the $\beta$ subunit adjacent to the exposed $\alpha$ subunit $[3,4]$. In addition, half of the $18 \alpha$ subunits contain a 200-amino acid inserted (I) domain which contributes to ligand recognition and specificity $[2,5]$.

During the last decade, the role of integrins in interactions of various cells with their microenvironment has become a focus of intensive research. Recent studies on monocytes, neutrophils, platelets, fibroblasts, endothelial, and pulmonary as well as intestinal epithelial cells (EC) demonstrated integrin involvement in regulation of virtually all vital cellular functions, including cell survival, proliferation, differentiation, migration, and cytokine production [reviewed by $1,6,7]$. Upon binding their extracellular ligands, integrins transmit outside-in signals that regulate various cellular functions. In addition, integrins are able to provide inside-out signaling regulating the affinity of integrin binding to its ligand, and such signaling can be induced by cellular activation with chemokines or cytokines. Hence, integrins act as bidirectional signaling molecules [1]. Several signaling pathways activated by integrin engagement were identified, such as mitogen-activated protein kinase (MAPK) and phosphatidylinositol 3-kinase (PI3-K) pathways [8, 9]. Integrins

\section{KARGER \\ Fax +4161306 1234 \\ E-Mail karger@karger.ch}

www.karger.com (c) 2008 S. Karger AG, Basel

1662-811X/09/0011-0004\$26.00/0

Accessible online at:

www.karger.com/jin
Dr. Marina Ulanova

Northern Ontario School of Medicine, Lakehead University, MS-3006 955 Oliver Road

Thunder Bay, ON P7B 5E1 (Canada)

Tel. +1 8077667340 , Fax +1 807766 7370,E-Mail marina.ulanova@normed.ca 
are involved in focal adhesion complexes comprising over 20 signaling and adaptor proteins, regulating actin cytoskeleton rearrangement and cell motility [10]. Binding of an integrin receptor to its ligand results in largescale conformational changes such as separation of the cytoplasmic domains of the $\alpha$ and $\beta$ subunits which causes cytoskeletal rearrangements and activation of downstream signaling [11]. According to the current concept, integrins act as specific sensors for dynamic changes in the microenvironment that occur during tissue development, inflammation, and tumorigenesis, and modulate cellular responses to these changes $[6,7,9]$.

Integrin receptors of leukocytes are vital in both innate and adaptive immune responses. In particular, $\beta 2$ integrins, such as LFA- $1(\alpha \mathrm{L} \beta 2)$ and Mac- $1(\alpha \mathrm{M} \beta 2)$, are essential for the activation of lymphocytes and for leukocyte migration during inflammatory responses. Congenital deficiency in $\beta 2$ integrins (i.e. the leukocyte adhesion deficiency) is characterized by recurrent, severe bacterial infections that are eventually fatal [12]. Recent studies have emphasized the importance of leukocyte integrins in the cross talk with immunoreceptors, including T cell receptor and $\mathrm{Fc}$ receptors, for immune responses [13]. However, the role of epithelial integrins in innate immune and inflammatory responses in mucosal tissues, such as pulmonary epithelium, remains poorly understood.

\section{Integrin Receptors in the Lung}

EC are currently recognized as primary elements generating inflammatory signals to activate other cells in the lung [14]. Pulmonary EC express an array of innate immune receptors, such as Toll-like receptors (TLR), as well as cytokine, growth factor and histamine receptors, involved in the regulation of dynamic interactions of the epithelium with the environment. Integrin receptors are significantly represented in pulmonary epithelium. Eight different integrin heterodimers are expressed in airway EC, i.e. $\alpha 2 \beta 1, \alpha 3 \beta 1, \alpha 6 \beta 4, \alpha 9 \beta 1, \alpha 5 \beta 1, \alpha v \beta 5, \alpha v \beta 6$, $\alpha v \beta 8$ [7]. These heterodimers recognize a range of ECM proteins: collagen I, tenascin C, laminins $5,10,11$, osteopontin, fibronectin (Fn), vitronectin (Vn), and others [7]. It is known that lung epithelial integrins are critical for maintaining epithelial integrity, repair of damaged cells, and regulation of cell differentiation and proliferation $[7$, 15]. The expression of integrin receptors in the respiratory epithelium is tightly regulated, and rapid increase in $\alpha 5 \beta 1$ integrin level in response to injury has been dem- onstrated [16]. Accordingly, integrin receptor ligands such as Fn, Vn, tenascin C, and osteopontin are rapidly induced at sites of epithelial damage or injury [7].

Despite the significant advances in the understanding the functions of pulmonary integrins, signaling pathways regulated by these receptors in the lung are still incompletely characterized. Lung epithelial integrins are known to provide co-stimulatory signals towards growth factor receptors, regulating cell survival and proliferation [reviewed by 7]. However, the co-stimulatory functions of pulmonary integrins appear to be wider and involve the cross talk with other receptors. We have recently found that $\beta 1$ integrins in human bronchial EC provide costimulatory signals that increase TNF-induced proinflammatory responses [17]. Interestingly, integrin-mediated responses in these cells involved activation of the nonreceptor protein tyrosine kinase (PTK) Syk recently discovered in the respiratory epithelium [17].

\section{The Role of Integrin Receptors in Recognition of Pathogenic Microorganisms}

Several significant human pathogens are known to utilize integrins and exploit integrin-mediated signaling to invade various types of host cells. Such mechanisms can be advantageous to the microorganisms, because the invasion of host cells often confers protection against the immune response, and may facilitate microbial growth and spreading to other cells. On the other hand, the resulting integrin-mediated signaling is potentially important for innate immune and inflammatory responses to the pathogen. As a variety of pathogens (bacteria, viruses, and fungi) bind integrins and elicit integrin-mediated signaling, it seems likely that integrins may serve as pathogen recognition receptors.

Several pathogenic bacteria are able to bind integrin receptors directly, via some specific adhesins. These are typically not respiratory pathogens but ones that rather invade other mucosal tissues such as the gastrointestinal epithelium (Yersinia enterocolitica, Y. pseudotuberculosis [18-21] and Helicobacter pylori [22]), or urethral epithelium (Neisseria gonorrhoeae [23]). The best-studied example of bacteria directly binding and exploiting integrin-mediated signaling mechanisms is the enteric pathogen Y.pseudotuberculosis [reviewed by 24]. These bacteria possess an outer membrane protein (OMP) invasin that binds to the $\beta 1$ subunit of five integrin heterodimers $(\alpha 3 \beta 1, \alpha 4 \beta 1, \alpha 5 \beta 1, \alpha 6 \beta 1$ and $\alpha v \beta 1)$ expressed on microfold (M) cells in Peyer's patches of the small intestine [18]. 
Table 1. Respiratory bacterial pathogens that exploit integrins or their ECM ligands during infection

\begin{tabular}{|c|c|c|c|c|}
\hline Bacteria & $\begin{array}{l}\text { Bacterial structures } \\
\text { interacting with integrins }\end{array}$ & Integrins involved & Results of bacterial interactions with integrins & Ref. No. \\
\hline S. aureus & FnBP A or B & $\alpha 5 \beta 1$ & $\begin{array}{l}\text { Adhesion/invasion } \\
\text { Activation of FAK and Src signaling } \\
\text { ILK-dependent internalization }\end{array}$ & $\begin{array}{l}39-41 \\
46-48 \\
49\end{array}$ \\
\hline \multirow[t]{2}{*}{ S. pyogenes } & $\begin{array}{l}\text { M1 protein } \\
\text { PrtF1/SfbI }\end{array}$ & $\alpha 5 \beta 1$ & $\begin{array}{l}\text { Adhesion/invasion of lung EC } \\
\text { ILK activation } \\
\text { Paxillin phosphorylation-dependent internalization }\end{array}$ & $49,57,60$ \\
\hline & Scl1 & $\alpha 2 \beta 1$ & Adhesion/invasion of lung EC & 64 \\
\hline $\begin{array}{l}\text { Mycobacterium } \\
\text { species }\end{array}$ & $\begin{array}{l}\text { FAP } \\
\text { Antigen } 85 B\end{array}$ & $\alpha 5, \alpha \mathrm{v}, \beta 1, \beta 3$ & Adhesion to and invasion of lung EC & 66,73 \\
\hline P. aeruginosa & Putative $50 \mathrm{kDa}$ OMP & $\alpha 5 \beta 1$ or $\alpha v \beta 5$ & Adhesion to and invasion of lung EC & $76,78,79$ \\
\hline H. influenzae & Hap & $\begin{array}{l}\alpha 5 \beta 1, \text { potentially } \\
\alpha 3 \beta 1, \alpha v \beta 6\end{array}$ & $\begin{array}{l}\text { Involved with TLR- } 4 \text { and platelet-activating factor } \\
\text { receptor-dependent uptake by } \mathrm{M} \text { cells }\end{array}$ & 92,93 \\
\hline S. pneumoniae & PavA FnBP & $\alpha 5 \beta 1 ?$ & Unclear, associated with adherence and invasion of EC & 93,94 \\
\hline
\end{tabular}

Binding of invasin to integrin receptors leads to formation of focal adhesion complexes and subsequent activation of intracellular signaling [20]. The resulting activation of the guanosine triphosphatase (GTPase) Racl causes cytoskeletal rearrangement, mediating bacterial internalization [reviewed by 25].

Some bacteria have the ability to bind integrins both directly and indirectly through an ECM ligand. For example, Borrelia burgdorferi, the causative agent of Lyme disease, possesses an Fn-binding protein (FnBP) BBK32 [26]. In addition, $B$. burgdorferi has an $\alpha 3 \beta 1$ integrinbinding protein $\mathrm{BBB} 07$ which directly activates proinflammatory responses in human chondrocytes [27, 28], as well as an $\alpha \mathrm{v} \beta 3$-binding OMP P66 which mediates bacterial adhesion to host cells [29].

However, the majority of integrin-binding microorganisms interact with integrins indirectly using ECMbinding proteins as a molecular bridge to engage these receptors. In these cases, integrin receptors recognize the common arginine-glycine-aspartate (RGD) sequence that is present in ECM proteins, such as Fn or Vn [30]. The resulting integrin-mediated signaling does not seem to depend on the type of the interactions, as both direct and indirect binding to integrins lead to tyrosine kinase phosphorylation, recruitment of adaptor molecules, and cytoskeletal rearrangement required for bacterial engulf- ment, as well as induction of proinflammatory cellular responses. However, the number of known microbial ECM-binding adhesins greatly outweighs those that bind integrins directly.

Several clinically significant bacterial pathogens target lung epithelial integrins, and this review will focus on exploring various structures and mechanisms involved in these interactions (summarized in table 1).

\section{Staphylococcus aureus}

S. aureus is an important pathogen causing nosocomial pneumonia as well as an initial lung infection in cystic fibrosis (CF) patients frequently followed by Pseudomonas aeruginosa [31]. The exploitation of ECM products and integrins by $S$. aureus during the infectious process was recently discussed in an excellent review by Hauck and Ohlsen [32].

The ability of $S$. aureus to bind Fn is mediated by the FnBP that exists as two variants, A and B, encoded on two closely related genes [33]. S. aureus FnBP adheres strongly to the N-terminal of Fn [34], specifically to the five type I-module amino terminal repeat motif of Fn [35], exploiting the modular structure of Fn by forming a tandem $\beta$-zipper attachment site [36]. 
S. aureus exploit the adhesion to Fn by using the latter as a molecular bridge between bacteria and host integrins, allowing the bacteria adhere to the cell surface and also to invade the host cells by becoming internalized [reviewed by 37, 38]. The use of Fn to bind to $\alpha 5 \beta 1$ integrins on host cells was originally proposed by Sinha et al. [39] based on the ability of $\beta 1$ antibody to inhibit $S$. aureus invasion of human embryonic kidney cells, and these findings were supported by similar studies using HeLa EC and endothelial cells [40, 41].

$S$. aureus $\alpha$-toxin is secreted by the bacterium during later stages of infection, and can interact with $\beta 1$ integrins resulting in decreased adhesion and invasion of the pathogen. The interaction of $\alpha$-toxin with $\beta 1$ integrin inhibits bacterial adhesion via the Fn bridge, thus eliminating cell signaling activation that would cause the internalization. This is an elegant example of a bacterial interference with the adhesion/invasion cell machinery during the later stages of infection, when it may be advantageous for the pathogen to seek out new infectious targets [42]. Although the molecular mechanisms of interactions between $S$. aureus $\alpha$-toxin and integrin receptors remain undefined, a recent study suggests a possibility of a direct binding of the $\alpha$-toxin to $\alpha 5 \beta 1$ integrin in lung EC [43]. Such interactions can be potentially involved in the pathogenesis of staphylococcal pneumonia as the $\alpha$-toxin-induced death of EC was found to be partially mediated by $\alpha 5 \beta 1$ integrin [43].

A number of studies suggest that the internalization of $S$. aureus depends on cellular events initiated by integrin receptors following bacterial adhesion [39, 44]. PTKs, which can be found in integrin-associated signaling complexes, are activated by the engagement of $\beta 1$ integrins and involved in S. aureus internalization [45]. More specifically, it is the signaling via the Src family of PTKs that is necessary, since Src inhibitors and certain Src-deficient cell lines show decreased $S$. aureus uptake [46, 47]. Focal adhesion kinase (FAK) is another PTK whose inhibition results in decreased $S$. aureus invasion, suggesting a role of FAK as a signaling intermediate between integrins and Src [48]. The serine-threonine protein kinase integrinlinked kinase (ILK) is attached to the actin cytoskeleton, and is also necessary for S. aureus uptake, emphasizing the importance of actin remodeling for the internalization of bacteria [49]. In addition, $S$. aureus binding to integrins via FnBP can activate actin remodeling that results in increased bacterial motility on the cell surface preceding the internalization [50]. Hence, binding of S. aureus to $\alpha 5 \beta 1$ integrin via FnBP activates signaling pathways that can mediate host responses to the pathogen.

Pulmonary Integrins as Immune Recognition Receptors
Although interactions of $S$. aureus with airway EC are incompletely understood, $S$. aureus adhesion to these cells has been shown to be significantly dependent on the presence of a functional FnBP, suggesting the involvement of integrins in this process [51]. However, the role of integrins in the internalization of $S$. aureus by pulmonary EC has not been directly addressed.

\section{Streptococcus pyogenes}

S. pyogenes is an important pathogen that primarily infects the skin and epithelium of the upper respiratory tract. S. pyogenes can cause severe pneumonia, as well as wound infections, septicemia, and endocarditis [52]. It has been known since the 1980s that $S$. pyogenes is capable of binding Fn, and that the attachment to ECM proteins may be important in invasion of the epithelium [53, 54]. This is now understood to be due to numerous FnBPs present on the surface of S. pyogenes, particularly $\mathrm{M} 1$ protein and PrtF1/SfbI [55]. Cue et al. [56] found that S. pyogenes binding of Fn via M1 protein was critical for invasion of EC, and that this process was abrogated by antibodies to $\alpha 5 \beta 1$ integrin. Using integrin inhibitors, it was demonstrated that the invasion of EC by streptococci was mediated by formation of integrin $\alpha 5 \beta 1-F n-M 1$ protein complexes [57]. However, M1-/SfbI+ strains of S. pyogenes are also capable of invading EC in an integrinmediated fashion suggesting the redundancy in the mechanisms of bacterial pathogenesis $[58,59]$. More recent studies have demonstrated that blocking of ILK, a key molecule in integrin-mediated signaling, abolished S. pyogenes uptake [49]. Downstream of ILK, phosphorylation of the adaptor protein paxillin has been shown to be crucial in M1+S. pyogenes internalization [60]. These findings provide clear evidence that $S$. pyogenes utilize integrins as receptors during EC invasion.

It has been suggested that streptococci may induce upregulation of integrins in EC to allow for increased bacterial adhesion and internalization. Indeed, during infection of lung EC with $S$. pyogenes, gene transcription of $\alpha 5$ integrin and Fn greatly increased and was followed by an increase in both $\alpha 5$ integrin and Fn protein expression by EC [61]. Moreover, S. pyogenes are able to induce active transforming growth factor (TGF)- $\beta_{1}$ production in human tonsil fibroblasts, and TGF- $\beta_{1}$ in turn upregulates the expression of both $\alpha 5$ integrin and Fn [62]. As a result of an increased $\alpha 5 \beta 1$ integrin expression, a subsequent increase in streptococcal invasion occurred, this time in an FnBP-dependent manner [62]. The latter study also

Innate Immun 2009;1:4-17 
suggested that $S$. pyogenes-infected fibroblasts can represent chronic sources of TGF- $\beta_{1}$ in vivo, causing upregulation of integrins in the surrounding epithelium. Interestingly, there appears to be a reciprocal interaction between TGF- $\beta$ and integrin receptors, as $\alpha \mathrm{v} \beta 6$ integrin can bind TGF- $\beta$ latency-associated peptide and activate TGF- $\beta$ [63]. This study suggested that the complex interplay involving TGF- $\beta$ and integrin $\alpha v \beta 6$ in lung EC initiated by microbial compounds is critical in lung innate immune defense [63].

In addition to the well-known process of streptococcal internalization mediated by the FnBP, there is a possibility of direct interactions of these pathogens with integrin receptors. A recent study demonstrated that $S$. pyogenes can adhere to and become internalized by human pharyngeal EC via a direct interaction between the collagenlike bacterial protein Scl1 and the epithelial collagen receptor, $\alpha 2 \beta 1$ integrin [64]. The authors suggested that this novel molecular mechanism can contribute to the bacterial pathogenesis as it enhances streptococcal intracellular survival and reemergence from infected cells [64].

\section{Mycobacteria}

Pathogenic mycobacteria, including the cause of the most significant infectious disease worldwide Mycobacterium tuberculosis, possess remarkable abilities to evade the immune system of the infected host. Interaction of M. tuberculosis with alveolar macrophages allowing these bacteria to survive and even replicate within the phagocytic cells is a hallmark of pulmonary tuberculosis, and has been studied extensively [65]. However, the mycobacteria also invade EC in the respiratory mucosa, and this may represent the site of primary uptake of bacteria during the infection process [66]. Although the molecular mechanisms behind mycobacterial invasion of pulmonary EC remain largely undefined, some data indicate that integrin receptors as well as their ECM protein ligands can be significantly involved. Fn was first implicated in M. bovis adherence to bladder epithelium [67, 68], and later it appeared that both attachment and internalization via Fn binding were highly conserved in mycobacteria [69]. Middleton et al. [70] demonstrated that M. tuberculosis adheres to ECM components at least in part via an Fn attachment protein (FAP) and antigen 85B protein, the latter also being involved in Fn binding [71]. Similarly, $M$. avium adheres to Fn via FAP in areas of epithelial damage [72].
As the ECM proteins are natural ligands for integrins, such bacteria-ECM interactions may serve to bridge mycobacteria to integrin receptors. Indeed, a study by Bermudez and Goodman [66] demonstrated that M. tuberculosis invasion of A549 type II alveolar pneumocytes was greatly inhibited by treating cells with anti- $\alpha \mathrm{v}$ or anti- $\beta 1$ integrin antibodies, and nearly abolished when treating them with both. Secott et al. [73] showed similar inhibition of M. paratuberculosis adhesion to and invasion of bovine intestinal EC following treatment with blocking peptides or neutralizing antibodies to $\alpha 5, \alpha \mathrm{v}$, $\beta 1$, and $\beta 3$ integrins. These studies indicate that various ECM components can serve as a molecular bridge between mycobacteria and integrins, and that multiple integrins can potentially mediate mycobacterial invasion of epithelium. Interestingly, a recent study implicated $\beta 1$ integrins, along with TLR-2 and ADAM9, in macrophage fusion during formation of tuberculous granulomas, representing a critical event in the pathogenesis of pulmonary tuberculosis, although the precise mechanisms of integrin involvement in this process remain unknown [74].

\section{Pseudomonas aeruginosa}

The opportunistic Gram-negative pathogen P. aeruginosa causes acute life-threatening infections in immunocompromised patients. It is also the leading cause of ventilator-associated pneumonia in intensive care units and of burn wound infections with high mortality rates. $P$. aeruginosa is the major cause of chronic pulmonary infection in CF patients [75]. Both integrin receptors and their ligands have been implicated in adhesion and internalization of $P$. aeruginosa in the lung epithelia. A number of studies demonstrated the ability of $P$. aeruginosa to bind Fn [76, 77] and Vn [78], the $\alpha 5 \beta 1$ and $\alpha v \beta 5$ integrin ligands, respectively. Some papers suggest that $\alpha v \beta 5$ and $\alpha 5 \beta 1$ integrins can also directly mediate $P$. aeruginosa adherence to and invasion of respiratory EC $[76,78,79]$. The molecular mechanisms of such interactions have not yet been defined, although a 50-kDa OMP of $P$. aeruginosa was found associated with $\alpha 5 \beta 1$ integrins in respiratory EC [79].

In the process of epithelial injury and repair, the expression of $\alpha 5 \beta 1$ receptors is increased with their redistribution from basolateral to apical sides, and respiratory EC synthesize large amounts of Fn potentially providing a basis for an enhanced adherence of $P$. aeruginosa [79]. Adherence of $P$. aeruginosa to laminin, another compo- 
nent of the ECM and the $\alpha 3 \beta 1$ integrin ligand, unmasked following epithelial injury, was also implicated in bacterial colonization of injured tissues [80].

Our recent observations have demonstrated that $P$. aeruginosa infection caused a rapid upregulation of integrins $\alpha 5, \alpha v, \beta 1$, and $\beta 4$ in A549 type II pneumocytes [Gravelle et al., unpubl. data]. Interestingly, this effect required live bacteria possessing intact pili and lipopolysaccharide (LPS), because heat-killed, pili-deficient, or outer-core oligosaccharide-deficient $P$. aeruginosa mutants did not alter the expression of integrins [Gravelle et al., unpubl. data]. These findings imply that pulmonary epithelial integrins can be involved in recognition of specific microbial products of $P$. aeruginosa and hence be important in innate immune responses to this pathogen.

\section{Bordetella pertussis}

The Gram-negative coccobacillus $B$. pertussis is the causative agent of whooping cough. The bacteria possess a number of virulence factors that are capable of exploiting integrin receptors of both pulmonary EC and monocytes/macrophages in the process of microbial pathogenesis. The major B. pertussis adhesin, filamentous hemagglutinin (FHA), contains an RGD sequence which allows the bacterium to invade alveolar macrophages by binding to $\alpha \mathrm{M} \beta 2$ integrin $[81,82]$, as well as airway EC by binding to $\alpha 5 \beta 1$ integrin [83].

The interactions of FHA with $\alpha \mathrm{M} \beta 2$ integrin are essential for $B$. pertussis internalization into macrophages and intracellular survival [82]. B. pertussis binding to $\alpha \mathrm{M} \beta 2$ integrin activates cell signaling pathways which lead to upregulation of $\beta 3$-containing integrins and the integrin-associated protein CD47, which in turn upregulates $\alpha \mathrm{M} \beta 2$ [84]. The bacterium is thus able to exploit integrins using a positive feedback loop, resulting in increased survival and persistence at the site of infection. In addition, $B$. pertussis produces a repeat in toxin (RTX) adenylate cyclase toxin called CyaA, which further exploits $\alpha M \beta 2$ integrins in macrophages by binding them and subsequently converting cellular ATP to cAMP, suppressing the bactericidal activities of these cells [reviewed by 85$]$. Recent studies demonstrated that via interaction with $\alpha \mathrm{M} \beta 2$ integrins, the adenylate cyclase toxin also induces cyclooxygenase 2 (COX-2) in macrophages. The latter protein can then significantly contribute to the inflammatory responses caused by B. pertussis [86].
B. pertussis is also able to invade host EC through the interactions of FHA with $\alpha 5 \beta 1$ integrins [83]. Such interactions appeared to be important not only for bacterial invasion, but also for inflammatory responses. Indeed, in vitro engagement of $\alpha 5 \beta 1$ integrins by FHA caused RGDdependent activation of nuclear factor kappa B (NF- $\mathrm{B}$ ) and, as a result, up-regulation of intercellular adhesion molecule-1 (ICAM-1) expression in lung EC $[87,88]$.

\section{Haemophilus influenzae}

H. influenzae are Gram-negative commensal bacteria commonly found in the upper respiratory tract but they also can cause respiratory diseases such as pneumonia, as well as invasive systemic infections [89]. The major virulence factor of $H$. influenzae is the polysaccharide capsule. Encapsulated strains of $H$. influenzae are designated as types a, b, c, d, e, and f according to their capsular antigens, type $b$ being the most important clinically and causing severe invasive diseases, i.e. meningitis, epiglottitis, and septicemia. $H$. influenzae that lack capsular polysaccharides are referred to as nontypeable and are less virulent. Many clinical isolates of nontypeable $H$. influenzae are able to bind ECM proteins [90]. For example Hap, an ubiquitous nonpilus adhesin of $H$. influenzae, specifically binds to Fn, laminin and collagen IV, and such interactions mediate bacterial adhesion to the ECM [91]. These data suggest that $H$. influenzae can indirectly bind integrin receptors representing the natural ligands for these ECM proteins in the respiratory epithelium, i.e. $\alpha 5 \beta 1, \alpha 3 \beta 1, \alpha v \beta 6$ [7]. However, integrin involvement in adherence of $H$. influenzae to the respiratory epithelium has not been directly explored. Nevertheless, the uptake of nontypeable $H$. influenzae by $\mathrm{M}$ cells in the intestinal epithelium was mediated by $\alpha 5 \beta 1$ integrin along with TLR-4 and platelet-activating factor receptor, as demonstrated by the blocking of translocation of bacteria into $M$ cells in the presence of specific receptor inhibitors [92].

\section{Streptococcus pneumoniae}

The leading cause of community-acquired pneumonia, S. pneumoniae (pneumococcus), possesses an FnBP protein PavA essential for the virulence [93]. PavA is structurally homologous to the FnBP of other pathogenic bacteria such as $S$. pyogenes and S. gordonii [94]. It is possible that adhesion to and invasion of lung EC that is 
critical in the pathogenesis of pneumococcal pneumonia can be mediated by Fn- $\alpha 5 \beta 1$ integrin interactions, as in case of other infections. However, the direct role of PavA in pathogen-host interactions and inflammatory responses caused by $S$. pneumoniae remains to be determined.

\section{Other Microbes}

Integrins are also implicated in the pathogenesis of some fungal and viral pulmonary infections. The fungus Pneumocystis carinii, a major cause of acute pneumonia in AIDS patients, uses an FnBP to adhere to $\alpha \mathrm{v}$ and $\alpha 5$ integrins $[95,96]$. Furthermore, $P$. carinii is able to induce upregulation of integrins, possibly enhancing its own adherence to lung EC [97]. Interestingly, some pathogenic fungi, such as Pneumocystis species and Candida albicans, possess molecules with integrin-like features that mediate fungal adhesion to Fn $[98,99]$. A novel Pneumocystis molecule PCINT1 with significant structural features of an integrin-like adhesion receptor has been recently characterized [99]. The results of the latter study suggest an important role of this molecule in pathogenhost lung EC interactions during Pneumocystis pneumonia [99].

A number of viruses that infect the respiratory epithelium have been shown to use integrin receptors for both cell entry and induction of intracellular signaling important for disease pathogenesis. Some examples include members of adenovirus, herpesvirus, hantavirus, picornavirus, Reoviridae families [reviewed by 100]. Such viruses directly bind to a variety of integrins present in the respiratory epithelium, e.g. $\alpha 2 \beta 1, \alpha 3 \beta 1, \alpha 5 \beta 1$, $\alpha v \beta 5, \alpha v \beta 6$, and use them as receptors to attach to the cells and enter them. The mechanisms of virus interactions with integrins and their significance for viral pathogenesis have been recently discussed in a comprehensive review [100]. Several viruses, e.g. Coxsackieviruses, foot-and-mouth disease viruses, human parechoviruses, and echoviruses possess a functional RGD motif in one of their capsid proteins that allow viruses to bind integrins, i.e. $\alpha v \beta 3$ or $\alpha v \beta 6$ [101]. Interactions of viruses with integrin receptors are proven to be important in the pathogenesis of a variety of conditions ranging from acute upper respiratory tract infections and foot-and-mouth disease to highly lethal hantavirus pulmonary syndrome [100]. Recent data implicate that the severe acute respiratory syndrome-related coronavirus possesses the ability of binding to integrin I do- mains [102]. However, it is still unclear whether integrin-mediated interactions are involved in coronavirus entry into lung EC.

\section{Integrins as Innate Recognition Receptors}

According to the current concept, the recognition of pathogen-associated molecules is critical for innate immunity. Among the pattern recognition receptors (PRRs), TLRs are key molecules that sense the invasion of pathogens based on their typical molecular structures, such as LPS, peptidoglycans, flagella, single-stranded or doublestranded RNA, CpG DNA, etc. [103]. Such structures are unique to microorganisms in contrast to metazoans, and therefore allow for discrimination between self and nonself that is essential for immune defense [103]. Upon their activation, TLRs induce signal transduction leading to inflammatory responses and eventually to elimination of the invader. However, microorganisms are capable of binding various receptors of host cells resulting in complex cellular responses. It has now been recognized that there exists a huge diversity in innate immune receptors, in addition to the best-studied TLRs. The importance of non-TLR PRRs, such as Nod-like receptors, C-type lectins, scavenger receptors, or protease-activated receptors, as integral components of innate immune recognition, has been recently discussed in several excellent reviews [104-106]. The role of integrins as PRRs is still unclear, although leukocyte integrins serving as complement receptors, e.g. Mac-1, are recognized as PRRs for certain pathogens [107]. The role of epithelial integrins in innate immunity is even less understood, despite the fact that these receptors are highly expressed in mucosal surfaces, such as airway EC.

We propose that lung epithelial integrins may act as PRRs based on both their significance in many hostpathogen interactions and on common characteristics with other PRRs, such as TLRs (table 2). Like TLR, integrin receptors are germline-encoded and highly conserved in the evolution, present in all metazoans including invertebrates, e.g. ascidians, nematode worms and Drosophila [108]. As outlined above, integrins are able to bind a wide variety of microorganisms, including both Gram-positive and Gram-negative bacteria, viruses, and fungi. Moreover, it has been demonstrated that integrin receptors are able to sense diverse pathogen-associated molecular structures, although many of the specific ligands involved in such pathogen-host interactions are still unknown. Interestingly, a variety of microorgan- 
Table 2. Characteristics of integrin receptors shared with other PRRs, i.e. TLRs

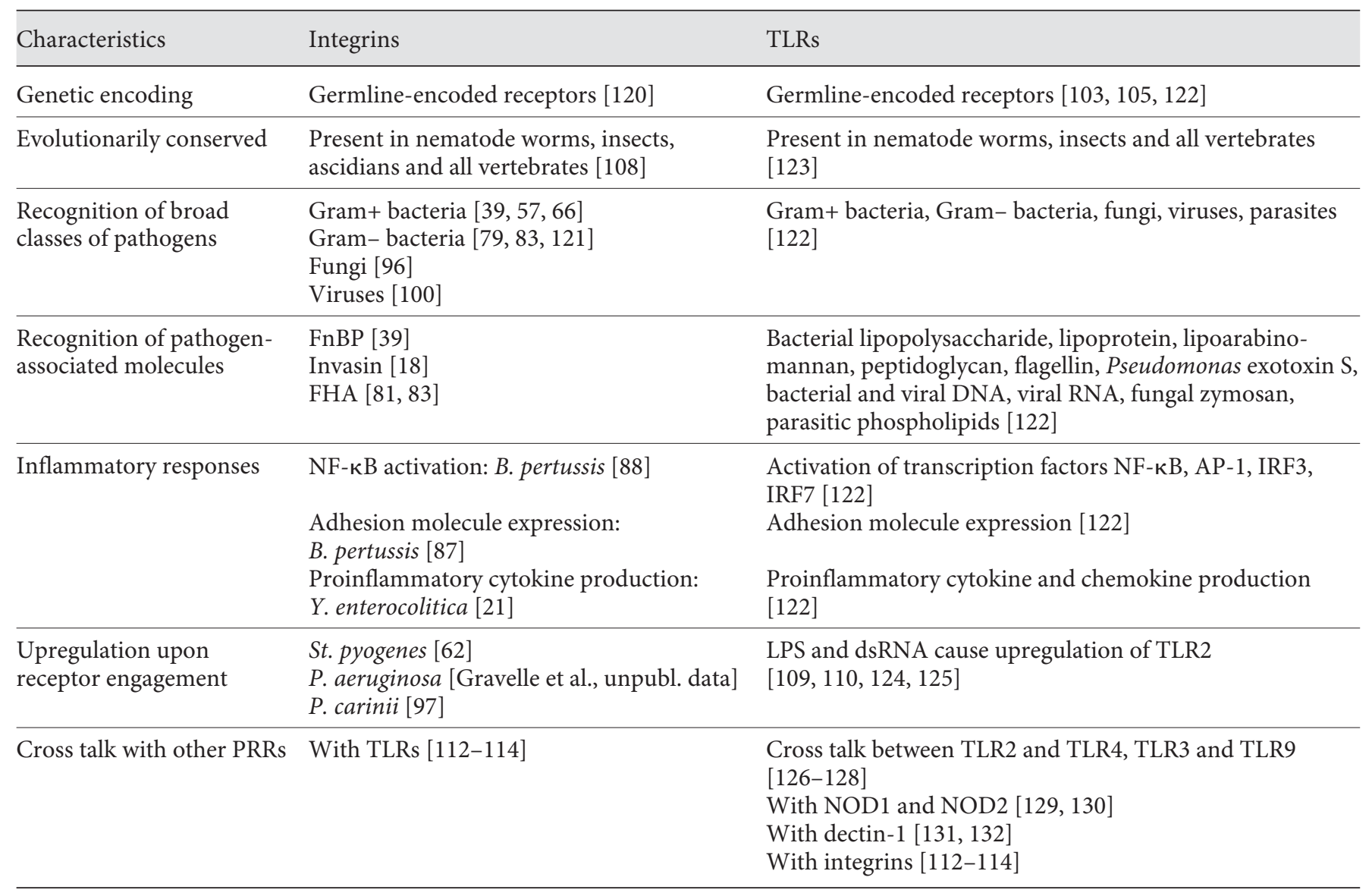

AP-1 = Activator protein 1; dsRNA = double-stranded RNA; IRF = interferon regulatory factor; NOD = nucleotide-binding oligomerization domain.

isms, i.e. S. aureus, S. pyogenes, mycobacteria, S. pneumoniae, possess various Fn-binding proteins allowing interactions with integrin heterodimers using Fn as a molecular bridge. Remarkably, the subsequent cellular responses are different from those elicited by Fn alone. Some other pathogens bind directly to integrins, forgoing the use of ECM proteins. For example, Y. pseudotuberculosis invasin interacts directly with $\beta 1$ integrins, as does $B$. pertussis FHA $[18,81,83]$. Interestingly, FHA binds to integrins via an RGD domain like the interaction between integrin receptors and their natural ECM ligands (fig. 1).

As in case of other PRRs, integrin engagement by pathogenic microorganisms results in activation of cellular responses important for innate immunity and inflammation. The hallmark of such responses is the activation of the transcription factor NF- $\mathrm{KB}$ followed by transcriptional regulation of proinflammatory cytokine, chemokine, and adhesion molecule (ICAM-1) expression. Indeed, integrin receptor engagement by some pathogenic bacteria, such as B. pertussis and Y. pseudotuberculosis caused NF- $\mathrm{BB}$-mediated proinflammatory cellular responses [21, 88] (fig. 2).

It is known that PRRs, i.e. TLRs, can be upregulated upon their engagement enhancing host responses to infection [109-111]. Similarly, integrins can be upregulated during infection as demonstrated in models of $S$. pyogenes [62], P. carinii [97] and P. aeruginosa infections [Gravelle et al., unpubl. data].

It is recognized that TLRs as well as other PRRs are engaged in an integrated signaling cross talk [105]. Similarly, some recent studies identified integrins as important components of signaling complexes involved in cellular responses to pathogen-associated molecular pat- 


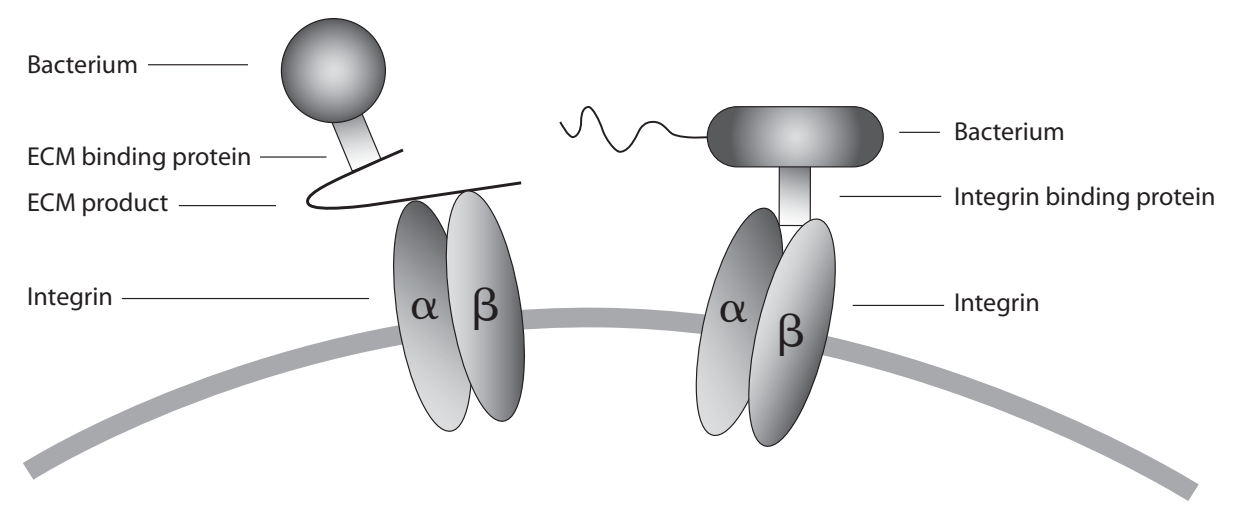

Microbes using ECM products to bind integrins

\begin{tabular}{|c|c|c|c|}
\hline Microbe & $\begin{array}{l}\text { ECM binding } \\
\text { protein }\end{array}$ & $\begin{array}{l}\text { ECM } \\
\text { product }\end{array}$ & Integrin \\
\hline $\begin{array}{l}\text { Staphylococcus } \\
\text { aureus }\end{array}$ & $\mathrm{FnBP}$ & $\mathrm{Fn}$ & $\alpha 5 \beta 1$ \\
\hline $\begin{array}{l}\text { Streptococcus } \\
\text { pyogenes }\end{array}$ & $\begin{array}{l}\text { M1 protein, } \\
\text { PrtF1/Sfbl }\end{array}$ & $\mathrm{Fn}$ & $\alpha 5 \beta 1$ \\
\hline $\begin{array}{l}\text { Pseudomonas } \\
\text { aeruginosa }\end{array}$ & Putative OMP & $\mathrm{Fn}, \mathrm{Vn}$ & $\begin{array}{l}\alpha 5 \beta 1, \\
\alpha \vee \beta 5\end{array}$ \\
\hline $\begin{array}{l}\text { Streptococcus } \\
\text { pneumoniae }\end{array}$ & PavA & $\mathrm{Fn}$ & $\alpha 5 \beta 1$ \\
\hline $\begin{array}{l}\text { Haemophilus } \\
\text { influenzae }\end{array}$ & unknown & $\mathrm{Fn}$ & $\alpha 5 \beta 1$ \\
\hline Mycobacterium & FAP, Antigen 85B & $\mathrm{Vn}$ ? Fn? & $\alpha \mathrm{v}, \beta 1$ \\
\hline $\begin{array}{l}\text { Pneumocystis } \\
\text { carinii }\end{array}$ & $\mathrm{FnBP}$ & $\mathrm{Fn}$ & $\alpha \mathrm{v}, \beta 5$ \\
\hline
\end{tabular}

Microbes binding directly to integrins

\begin{tabular}{|lll|}
\hline Microbe & $\begin{array}{l}\text { Integrin binding } \\
\text { protein }\end{array}$ & Integrin \\
\hline $\begin{array}{l}\text { Bordetella } \\
\text { pertussis }\end{array}$ & FHA & $\alpha 5 \beta 1$ \\
$\begin{array}{l}\text { Streptococcus } \\
\text { pyogenes }\end{array}$ & Scl1 (proposed) & $\alpha 2 \beta 1$ \\
$\begin{array}{l}\text { Viruses (i.e: } \\
\text { coxsackievirus) }\end{array}$ & $\begin{array}{l}\text { RGD containing } \\
\text { capsid proteins }\end{array}$ & $\begin{array}{l}\alpha 5 \beta 1, \alpha 3 \beta 1, \\
\alpha 5 \beta 1, \alpha \mathrm{v} \beta 5, \\
\alpha \mathrm{V} \beta 6\end{array}$ \\
\hline
\end{tabular}

Fig. 1. The most important bacterial interactions with epithelial integrin receptors. Microorganisms can interact with lung epithelial integrins either directly via integrin-binding proteins or indirectly by using an extracellular martix protein, e.g. Fn or Vn, as a molecular bridge to engage these receptors.

terns. Indeed, the activation of NF- $\mathrm{BB}$ and MAPK cascade induced in macrophages and intestinal EC lines by LPS stimulation required simultaneous engagement of integrin receptors providing essential co-stimulatory signals [112-114]. Although integrins appear to be critical for responses of some cell types to TLR agonists, the molecular interactions between integrins and signaling intermediates elicited by other PRRs are largely undefined.

\section{Conclusion}

Integrin receptors are complex molecules that mediate both physiological and pathological processes, e.g. inflammation and tumorigenesis. During the last decade, it has become clear that integrins significantly participate in various host-pathogen interactions involving pathogenic bacteria, fungi, and viruses. Many bacteria possess adhesins that can bind either directly or indirectly to integrins. However, there appears to be an emerging role for 


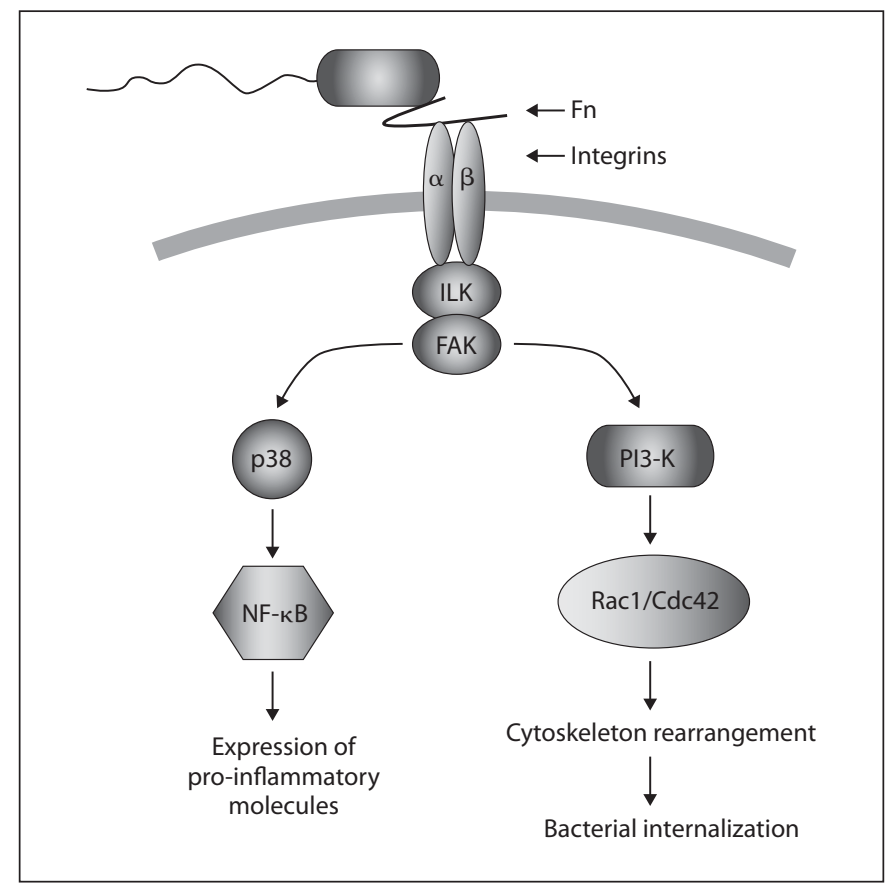

Fig. 2. Intracellular signaling pathways activated upon bacterial engagement of integrin receptors. Bacteria such as $S$. aureus or $S$. pyogenes bind Fn using it as a molecular bridge to bind integrins. Integrin receptor engagement causes activation of ILK and FAK. The resulting signaling cascade leads to inflammatory cellular responses, i.e. via phosphorylation of p38 MAPK and a subsequent activation and nuclear translocation of NF- $\kappa \mathrm{B}$ followed by gene expression of various proinflammatory molecules. Integrinmediated signaling also leads to cytoskeletal rearrangement and bacterial internalization via activation of PI3-K and small GTPases Rac1 and Cdc42. Some bacteria are also capable to bind integrins directly, which results in similar signaling events (not shown).

integrins beyond simply adhesion molecules. Given the extremely conserved nature of integrin structure and function, and the diversity of the pathogens which use integrins, it appears that they may act as PRRs, involved in bacterial recognition and initiation of the innate immune response.

However, the role of integrin receptors in host defense still remains poorly understood. Although a number of studies identified integrins as receptors used by pathogenic bacteria for their internalization by host cells, the significance of this process for innate immunity is not clearly defined. Internalization of bacteria may represent an important step in host defense. Indeed, internalized bacteria may be cleared due to inflammatory signaling initiated by intracellular Nod-like receptors and endo-

some-located TLRs, or as a result of apoptosis of infected cells. Furthermore, internalization may be critical in activation of adaptive immunity because infected cells, including mucosal EC, are able to present microbial antigens to lymphocytes $[115,116]$. However, although the results from some studies suggest the role of integrins as innate recognition receptors important for mucosal immune defense, there remain many questions to be answered.

Understanding the role of epithelial integrins in the pathogenesis of pulmonary infections may be important for developing new therapies targeting critical mechanisms of the pathogenesis of conditions such as acute bacterial pneumonia, chronic $P$. aeruginosa infection in CF patients, or fungal lung disease in immunocompromised patients. Of interest, aerosolized integrin inhibitors have been demonstrated to inhibit pulmonary inflammatory responses by blocking leukocyte infiltration into the lung using in vivo models of allergic asthma [117-119]. Although these studies did not investigate infectious processes, they demonstrated the feasibility of employing integrin inhibitors in vivo to suppress lung inflammation. Would it be possible to use integrin inhibitors to interfere with bacteria-host interactions to alleviate potentially detrimental integrin-mediated cellular responses? Although more studies into the mechanisms of pathogenintegrin interactions are required before this question can be answered, the inhibition of integrins may represent a promising new tool to combat pulmonary infections.

References

J Innate Immun 2009;1:4-17
1 Arnaout MA, Mahalingam B, Xiong JP: Integrin structure, allostery, and bidirectional signaling. Annu Rev Cell Dev Biol 2005;21: 381-410.

$\checkmark 2$ Luo BH, Carman CV, Springer TA: Structural basis of integrin regulation and signaling. Annu Rev Immunol 2007;25:619-647.

- 3 Xiong JP, Stehle T, Diefenbach B, Zhang R, Dunker R, Scott DL, Joachimiak A, Goodman SL, Arnaout MA: Crystal structure of the extracellular segment of integrin alpha Vbeta3. Science 2001;294:339-345.

4 Xiong JP, Stehle T, Zhang R, Joachimiak A, Frech M, Goodman SL, Arnaout MA: Crystal structure of the extracellular segment of integrin alpha Vbeta3 in complex with an Arg-Gly-Asp ligand. Science 2002;296:151155 .

5 Lee JO, Bankston LA, Arnaout MA, Liddington RC: Two conformations of the integrin A-domain (I-domain): a pathway for activation? Structure 1995;3:1333-1340. 
6 Giancotti FG, Ruoslahti E: Integrin signaling. Science 1999;285:1028-1032.

7 Sheppard D: Functions of pulmonary epithelial integrins: from development to disease. Physiol Rev 2003;83:673-686.

$>8$ Clark EA, Brugge JS: Integrins and signal transduction pathways: the road taken. Science 1995;268:233-239.

-9 Miranti CK, Brugge JS: Sensing the environment: a historical perspective on integrin signal transduction. Nat Cell Biol 2002;4: E83-90.

10 Geiger B, Bershadsky A: Assembly and mechanosensory function of focal contacts. Curr Opin Cell Biol 2001;13:584-592.

11 Kim M, Carman CV, Springer TA: Bidirectional transmembrane signaling by cytoplasmic domain separation in integrins. Science 2003;301:1720-1725.

12 Bunting M, Harris ES, McIntyre TM, Prescott SM, Zimmerman GA: Leukocyte adhesion deficiency syndromes: adhesion and tethering defects involving beta 2 integrins and selectin ligands. Curr Opin Hematol 2002;9:30-35.

13 Abram CL, Lowell CA: Convergence of immunoreceptor and integrin signaling. Immunol Rev 2007;218:29-44.

14 Diamond G, Legarda D, Ryan LK: The innate immune response of the respiratory epithelium. Immunol Rev 2000;173:27-38.

15 Sheppard D: Integrin-mediated activation of transforming growth factor-beta(1) in pulmonary fibrosis. Chest 2001;120:49S-53S.

16 Pilewski JM, Latoche JD, Arcasoy SM, Albelda SM: Expression of integrin cell adhesion receptors during human airway epithelial repair in vivo. Am J Physiol 1997;273:L256L263.

17 Ulanova M, Puttagunta L, Marcet-Palacios M, Duszyk M, Steinhoff U, Duta F, Kim MK, Indik ZK, Schreiber AD, Befus AD: Syk tyrosine kinase participates in beta1-integrin signaling and inflammatory responses in airway epithelial cells. Am J Physiol Lung Cell Mol Physiol 2005;288:L497-L507.

18 Isberg RR, Leong JM: Multiple beta 1 chain integrins are receptors for invasin, a protein that promotes bacterial penetration into mammalian cells. Cell 1990;60:861-871.

19 Rankin S, Isberg RR, Leong JM: The integrin-binding domain of invasin is sufficient to allow bacterial entry into mammalian cells. Infect Immun 1992;60:3909-3912.

20 Gustavsson A, Armulik A, Brakebusch C, Fassler R, Johansson S, Fallman M: Role of the betal-integrin cytoplasmic tail in mediating invasin-promoted internalization of Yersinia. J Cell Sci 2002;115:2669-2678.

21 Schmid Y, Grassl GA, Buhler OT, Skurnik M, Autenrieth IB, Bohn E: Yersinia enterocoliti$c a$ adhesin A induces production of interleukin-8 in epithelial cells. Infect Immun 2004; 72:6780-6789.
22 Kwok T, Zabler D, Urman S, Rohde M, Hartig R, Wessler S, Misselwitz R, Berger J, Sewald N, Konig W, Backert S: Helicobacter exploits integrin for type IV secretion and kinase activation. Nature 2007;449:862866.

23 Edwards JL, Apicella MA: I-domain-containing integrins serve as pilus receptors for Neisseria gonorrhoeae adherence to human epithelial cells. Cell Microbiol 2005;7:11971211.

24 Palumbo RN, Wang C: Bacterial invasin: structure, function, and implication for targeted oral gene delivery. Curr Drug Deliv 2006;3:47-53.

25 Wong KW, Isberg RR: Emerging views on integrin signaling via Racl during invasinpromoted bacterial uptake. Curr Opin Microbiol 2005;8:4-9.

26 Kim JH, Singvall J, Schwarz-Linek U, Johnson BJ, Potts JR, Hook M: BBK32, a fibronectin binding MSCRAMM from Borrelia burgdorferi, contains a disordered region that undergoes a conformational change on ligand binding. J Biol Chem 2004;279:4170641714.

27 Behera AK, Hildebrand E, Uematsu S, Akira $S$, Coburn J, Hu LT: Identification of a TLRindependent pathway for Borrelia burgdorferi-induced expression of matrix metalloproteinases and inflammatory mediators through binding to integrin alpha 3 beta 1 . J Immunol 2006;177:657-664.

28 Behera AK, Durand E, Cugini C, Antonara S, Bourassa L, Hildebrand E, Hu LT, Coburn $\mathrm{J}$ : Borrelia burgdorferi BBB07 interaction with integrin alpha(3)beta(1) stimulates production of pro-inflammatory mediators in primary human chondrocytes. Cell Microbiol 2008;10:320-331.

29 Coburn J, Cugini C: Targeted mutation of the outer membrane protein P66 disrupts attachment of the Lyme disease agent, Borrelia burgdorferi, to integrin alphavbeta3. Proc Natl Acad Sci USA 2003;100:7301-7306.

30 Ruoslahti E: RGD and other recognition sequences for integrins. Annu Rev Cell Dev Biol 1996;12:697-715.

31 Lowy FD: Staphylococcus aureus infections. N Engl J Med 1998;339:520-532.

32 Hauck CR, Ohlsen K: Sticky connections: extracellular matrix protein recognition and integrin-mediated cellular invasion by Staphylococcus aureus. Curr Opin Microbiol 2006;9:5-11.

33 Foster TJ, Hook M: Surface protein adhesins of Staphylococcus aureus. Trends Microbiol 1998;6:484-488.

34 Kuusela P, Vartio T, Vuento M, Myhre EB: Binding sites for streptococci and staphylococci in fibronectin. Infect Immun 1984;45: 433-436.

35 Sottile J, Schwarzbauer J, Selegue J, Mosher DF: Five type I modules of fibronectin form a functional unit that binds to fibroblasts and Staphylococcus aureus. J Biol Chem 1991; 266:12840-12843.
36 Schwarz-Linek U, Werner JM, Pickford AR, Gurusiddappa S, Kim JH, Pilka ES, Briggs JA, Gough TS, Hook M, Campbell ID, Potts JR: Pathogenic bacteria attach to human fibronectin through a tandem beta-zipper. Nature 2003;423:177-181.

37 Schwarz-Linek U, Hook M, Potts JR: The molecular basis of fibronectin-mediated bacterial adherence to host cells. Mol Microbiol 2004;52:631-641.

38 Hauck CR, Agerer F, Muenzner P, Schmitter T: Cellular adhesion molecules as targets for bacterial infection. Eur J Cell Biol 2006;85: 235-242.

39 Sinha B, Francois PP, Nusse O, Foti M, Hartford OM, Vaudaux P, Foster TJ, Lew DP, Herrmann M, Krause KH: Fibronectinbinding protein acts as Staphylococcus aureus invasin via fibronectin bridging to integrin alpha5beta1. Cell Microbiol 1999;1: 101-117.

40 Fowler T, Wann ER, Joh D, Johansson S, Foster TJ, Hook M: Cellular invasion by Staphylococcus aureus involves a fibronectin bridge between the bacterial fibronectin-binding MSCRAMMs and host cell betal integrins. Eur J Cell Biol 2000;79:672-679.

41 Massey RC, Kantzanou MN, Fowler T, Day NP, Schofield K, Wann ER, Berendt AR, Hook M, Peacock SJ: Fibronectin-binding protein A of Staphylococcus aureus has multiple, substituting, binding regions that mediate adherence to fibronectin and invasion of endothelial cells. Cell Microbiol 2001;3: 839-851.

42 Liang X, Ji Y: Alpha-toxin interferes with integrin-mediated adhesion and internalization of Staphylococcus aureus by epithelial cells. Cell Microbiol 2006;8:1656-1668.

43 Liang X, Ji Y: Involvement of alpha5beta1integrin and TNF-alpha in Staphylococcus aureus alpha-toxin-induced death of epithelial cells. Cell Microbiol 2007;9:1809-1821.

44 Jett BD, Gilmore MS: Internalization of Staphylococcus aureus by human corneal epithelial cells: role of bacterial fibronectinbinding protein and host cell factors. Infect Immun 2002;70:4697-4700.

45 Dziewanowska K, Patti JM, Deobald CF, Bayles KW, Trumble WR, Bohach GA: Fibronectin binding protein and host cell tyrosine kinase are required for internalization of Staphylococcus aureus by epithelial cells. Infect Immun 1999;67:4673-4678.

46 Fowler T, Johansson S, Wary KK, Hook M: Src kinase has a central role in in vitro cellular internalization of Staphylococcus aureus. Cell Microbiol 2003;5:417-426.

47 Agerer F, Michel A, Ohlsen K, Hauck CR: Integrin-mediated invasion of Staphylococcus aureus into human cells requires Src family protein-tyrosine kinases. J Biol Chem 2003; 278:42524-42531. 
48 Agerer F, Lux S, Michel A, Rohde M, Ohlsen K, Hauck CR: Cellular invasion by Staphylococcus aureus reveals a functional link between focal adhesion kinase and cortactin in integrin-mediated internalisation. J Cell Sci 2005;118:2189-2200.

49 Wang B, Yurecko RS, Dedhar S, Cleary PP: Integrin-linked kinase is an essential link between integrins and uptake of bacterial pathogens by epithelial cells. Cell Microbiol 2006;8:257-266.

50 Schroder A, Schroder B, Roppenser B, Linder S, Sinha B, Fassler R, Aepfelbacher M: Staphylococcus aureus fibronectin binding protein- $\mathrm{A}$ induces motile attachment sites and complex actin remodeling in living endothelial cells. Mol Biol Cell 2006;17:5198-5210.

51 Mongodin E, Bajolet O, Cutrona J, Bonnet N, Dupuit F, Puchelle E, de Bentzmann S: Fibronectin-binding proteins of Staphylococcus aureus are involved in adherence to human airway epithelium. Infect Immun 2002;70: 620-630.

52 Cunningham MW: Pathogenesis of group A streptococcal infections. Clin Microbiol Rev 2000;13:470-511.

53 Switalski LM, Ljungh A, Ryden C, Rubin K, Hook M, Wadstrom T: Binding of fibronectin to the surface of group A, C, and G streptococci isolated from human infections. Eur J Clin Microbiol 1982;1:381-387.

54 Myhre EB, Kuusela P: Binding of human fibronectin to group $\mathrm{A}, \mathrm{C}$, and $\mathrm{G}$ streptococci. Infect Immun 1983;40:29-34.

55 Talay SR, Valentin-Weigand P, Jerlstrom PG, Timmis KN, Chhatwal GS: Fibronectinbinding protein of Streptococcus pyogenes: sequence of the binding domain involved in adherence of streptococci to epithelial cells. Infect Immun 1992;60:3837-3844.

56 Cue D, Dombek PE, Lam H, Cleary PP: Streptococcus pyogenes serotype M1 encodes multiple pathways for entry into human epithelial cells. Infect Immun 1998;66:4593-4601.

57 Cue D, Southern SO, Southern PJ, Prabhakar J, Lorelli W, Smallheer JM, Mousa SA, Cleary PP: A nonpeptide integrin antagonist can inhibit epithelial cell ingestion of Streptococcus pyogenes by blocking formation of integrin alpha 5beta 1-fibronectin-M1 protein complexes. Proc Natl Acad Sci USA 2000;97: 2858-2863.

58 Molinari G, Talay SR, Valentin-Weigand P, Rohde M, Chhatwal GS: The fibronectinbinding protein of Streptococcus pyogenes, $\mathrm{SfbI}$, is involved in the internalization of group A streptococci by epithelial cells. Infect Immun 1997;65:1357-1363.

59 Molinari G, Rohde M, Guzman CA, Chhatwal GS: Two distinct pathways for the invasion of Streptococcus pyogenes in non-phagocytic cells. Cell Microbiol 2000;2:145-154.

60 Wang B, Li S, Dedhar S, Cleary PP: Paxillin phosphorylation: bifurcation point downstream of integrin-linked kinase (ILK) in streptococcal invasion. Cell Microbiol 2007; 9:1519-1528.
61 Klenk M, Koczan D, Guthke R, Nakata M, Thiesen HJ, Podbielski A, Kreikemeyer B: Global epithelial cell transcriptional responses reveal Streptococcus pyogenes Fas regulator activity association with bacterial aggressiveness. Cell Microbiol 2005;7:12371250

62 Wang B, Li S, Southern PJ, Cleary PP: Streptococcal modulation of cellular invasion via TGF-betal signaling. Proc Natl Acad Sci USA 2006;103:2380-2385.

63 Takabayshi K, Corr M, Hayashi T, Redecke V, Beck L, Guiney D, Sheppard D, Raz E: Induction of a homeostatic circuit in lung tissue by microbial compounds. Immunity 2006;24:475-487.

64 Caswell CC, Lukomska E, Seo NS, Hook M, Lukomski S: Scl1-dependent internalization of group A Streptococcus via direct interactions with the alpha2beta(1) integrin enhances pathogen survival and re-emergence. Mol Microbiol 2007;64:1319-1331.

65 Houben EN, Nguyen L, Pieters J: Interaction of pathogenic mycobacteria with the host immune system. Curr Opin Microbiol 2006; 9:76-85.

66 Bermudez LE, Goodman J: Mycobacterium tuberculosis invades and replicates within type II alveolar cells. Infect Immun 1996;64: 1400-1406.

67 Kuroda K, Brown EJ, Telle WB, Russell DG, Ratliff TL: Characterization of the internalization of bacillus Calmette-Guerin by human bladder tumor cells. J Clin Invest 1993; 91:69-76.

68 Ratliff TL, McCarthy R, Telle WB, Brown EJ: Purification of a mycobacterial adhesin for fibronectin. Infect Immun 1993;61:1889_ 1894.

69 Schorey JS, Li Q, McCourt DW, Bong-Mastek M, Clark-Curtiss JE, Ratliff TL, Brown EJ: A Mycobacterium leprae gene encoding a fibronectin binding protein is used for efficient invasion of epithelial cells and Schwann cells. Infect Immun 1995;63:2652-2657.

70 Middleton AM, Chadwick MV, Nicholson AG, Dewar A, Groger RK, Brown EJ, Ratliff TL, Wilson R: Interaction of Mycobacterium tuberculosis with human respiratory mucosa. Tuberculosis (Edinb) 2002;82:69-78.

71 Rambukkana A, Das PK, BurggraafJD, Yong S, Faber WR, Thole JE, Harboe M: Heterogeneity of monoclonal antibody-reactive epitopes on mycobacterial 30-kilodalton-region proteins and the secreted antigen 85 complex and demonstration of antigen $85 \mathrm{~B}$ on the Mycobacterium leprae cell wall surface. Infect Immun 1992;60:5172-5181.

72 Middleton AM, Chadwick MV, Nicholson AG, Dewar A, Groger RK, Brown EJ, Wilson $\mathrm{R}$ : The role of Mycobacterium avium complex fibronectin attachment protein in adherence to the human respiratory mucosa. Mol Microbiol 2000;38:381-391.
73 Secott TE, Lin TL, Wu CC: Mycobacterium avium subsp. paratuberculosis fibronectin attachment protein facilitates M-cell targeting and invasion through a fibronectin bridge with host integrins. Infect Immun 2004;72:3724-3732.

74 Puissegur MP, Lay G, Gilleron M, Botella L, Nigou J, Marrakchi H, Mari B, Duteyrat JL, Guerardel Y, Kremer L, Barbry P, Puzo G, Altare F: Mycobacterial lipomannan induces granuloma macrophage fusion via a TLR2dependent, ADAM9- and beta1 integrinmediated pathway. J Immunol 2007;178: 3161-3169.

75 Saiman L, Siegel J: Infection control in cystic fibrosis. Clin Microbiol Rev 2004;17:57-71.

76 Gagniere H, Di Martino P: Alpha5betal integrins and fibronectin are involved in adherence of the Pseudomonas aeruginosa ER97314 clinical strain to A549 cells. Folia Microbiol (Praha) 2004;49:757-762.

77 Barnes RJ, Leung KT, Schraft H, Ulanova M: Chromosomal $g f p$ labelling of Pseudomonas aeruginosa using a mini-Tn 7 transposon: application for studies of bacteria-host interactions. Can J Microbiol 2008;54:48-57.

78 Leroy-Dudal J, Gagniere H, Cossard E, Carreiras F, Di Martino P: Role of alphavbeta5 integrins and vitronectin in Pseudomonas aeruginosa PAK interaction with A549 respiratory cells. Microbes Infect 2004;6:875881.

79 Roger P, Puchelle E, Bajolet-Laudinat O, Tournier JM, Debordeaux C, Plotkowski MC, Cohen JH, Sheppard D, de Bentzmann S: Fibronectin and alpha5betal integrin mediate binding of Pseudomonas aeruginosa to repairing airway epithelium. Eur Respir J 1999;13:1301-1309.

80 Plotkowski MC, Tournier JM, Puchelle E: Pseudomonas aeruginosa strains possess specific adhesins for laminin. Infect Immun 1996;64:600-605.

81 Relman D, Tuomanen E, Falkow S, Golenbock DT, Saukkonen K, Wright SD: Recognition of a bacterial adhesion by an integrin: macrophage CR3 (alpha M beta 2, CD11b/ CD18) binds filamentous hemagglutinin of Bordetella pertussis. Cell 1990;61:13751382.

82 Saukkonen K, Cabellos C, Burroughs M, Prasad S, Tuomanen E: Integrin-mediated localization of Bordetella pertussis within macrophages: role in pulmonary colonization. J Exp Med 1991;173:1143-1149.

83 Ishibashi Y, Relman DA, Nishikawa A: Invasion of human respiratory epithelial cells by Bordetella pertussis: possible role for a filamentous hemagglutinin Arg-Gly-Asp sequence and alpha5betal integrin. Microb Pathog 2001;30:279-288.

84 Ishibashi Y, Claus S, Relman DA: Bordetella pertussis filamentous hemagglutinin interacts with a leukocyte signal transduction complex and stimulates bacterial adherence to monocyte CR3 (CD11b/CD18). J Exp Med 1994;180:1225-1233. 
85 Vojtova J, Kamanova J, Sebo P: Bordetella adenylate cyclase toxin: a swift saboteur of host defense. Curr Opin Microbiol 2006;9: 69-75.

86 Perkins DJ, Gray MC, Hewlett EL, Vogel SN: Bordetella pertussis adenylate cyclase toxin (ACT) induces cyclooxygenase-2 (COX-2) in murine macrophages and is facilitated by ACT interaction with CD11b/CD18 (Mac-1). Mol Microbiol 2007;66:1003-1015.

87 Ishibashi Y, Nishikawa A: Bordetella pertussis infection of human respiratory epithelial cells up-regulates intercellular adhesion molecule-1 expression: role of filamentous hemagglutinin and pertussis toxin. Microb Pathog 2002;33:115-125.

88 Ishibashi Y, Nishikawa A: Role of nuclear factor-kappa B in the regulation of intercellular adhesion molecule 1 after infection of human bronchial epithelial cells by Bordetella pertussis. Microb Pathog 2003;35:169177.

89 Turk DC: The pathogenicity of Haemophilus influenzae. J Med Microbiol 1984;18:1-16.

90 Bresser P, Virkola R, Jonsson-Vihanne M, Jansen HM, Korhonen TK, van Alphen L: Interaction of clinical isolates of nonencapsulated Haemophilus influenzae with mammalian extracellular matrix proteins. FEMS Immunol Med Microbiol 2000;28:129-132.

91 Fink DL, Green BA, St Geme JW 3rd: The Haemophilus influenzae Hap autotransporter binds to fibronectin, laminin, and collagen IV. Infect Immun 2002;70:4902-4907.

92 Tyrer P, Foxwell AR, Cripps AW, Apicella MA, Kyd JM: Microbial pattern recognition receptors mediate $\mathrm{M}$-cell uptake of a gramnegative bacterium. Infect Immun 2006;74: 625-631.

93 Pracht D, Elm C, Gerber J, Bergmann S, Rohde M, Seiler M, Kim KS, Jenkinson HF, Nau R, Hammerschmidt S: PavA of Streptococcus pneumoniae modulates adherence, invasion, and meningeal inflammation. Infect Immun 2005; 73:2680-2689.

94 Holmes AR, McNab R, Millsap KW, Rohde M, Hammerschmidt S, Mawdsley JL, Jenkinson HF: The pavA gene of Streptococcus pneumoniae encodes a fibronectin-binding protein that is essential for virulence. Mol Microbiol 2001;41:1395-1408.

95 Pottratz ST, Paulsrud J, Smith JS, Martin WJ 2nd: Pneumocystis carinii attachment to cultured lung cells by pneumocystis gp 120, a fibronectin binding protein. J Clin Invest 1991;88:403-407.

96 Pottratz ST, Weir AL: Attachment of Pneumocystis carinii to primary cultures of rat alveolar epithelial cells. Exp Cell Res 1995;221: 357-362.

97 Pottratz ST, Weir AL, Wisniowski PE: Pneumocystis carinii attachment increases expression of fibronectin-binding integrins on cultured lung cells. Infect Immun 1994;62: 5464-5469.
98 Gale C, Finkel D, Tao N, Meinke M, McClellan M, Olson J, Kendrick K, Hostetter $\mathrm{M}$ : Cloning and expression of a gene encoding an integrin-like protein in Candida albicans. Proc Natl Acad Sci USA 1996;93: 357-361.

99 Kottom TJ, Kennedy CC, Limper AH: Pneumocystis PCINT1, a molecule with integrin-like features that mediates organism adhesion to fibronectin. Mol Microbiol 2008;67:747-761.

100 Stewart PL, Nemerow GR: Cell integrins: commonly used receptors for diverse viral pathogens. Trends Microbiol 2007;15:500507.

101 Williams CH, Kajander T, Hyypia T, Jackson T, Sheppard D, Stanway G: Integrin alpha $v$ beta 6 is an RGD-dependent receptor for coxsackievirus A9. J Virol 2004;78: 6967-6973.

102 Hanel K, Stangler T, Stoldt M, Willbold D: Solution structure of the $\mathrm{X} 4$ protein coded by the SARS related coronavirus reveals an immunoglobulin like fold and suggests a binding activity to integrin I domains. J Biomed Sci 2006;13:281-293.

103 Medzhitov R: Recognition of microorganisms and activation of the immune response. Nature 2007;449:819-826.

104 Fritz JH, Ferrero RL, Philpott DJ, Girardin SE: Nod-like proteins in immunity, inflammation and disease. Nat Immunol 2006;7: 1250-1257.

105 Sansonetti PJ: The innate signaling of dangers and the dangers of innate signaling. Nat Immunol 2006;7:1237-1242.

106 Lee MS, Kim YJ: Signaling pathways downstream of pattern-recognition receptors and their cross talk. Annu Rev Biochem 2007;76:447-480.

107 Gasque P: Complement: a unique innate immune sensor for danger signals. Mol Immunol 2004;41:1089-1098.

108 Huhtala M, Heino J, Casciari D, de Luise A, Johnson MS: Integrin evolution: insights from ascidian and teleost fish genomes. Matrix Biol 2005;24:83-95.

109 Matsuguchi T, Musikacharoen T, Ogawa T, Yoshikai Y: Gene expressions of Toll-like receptor 2, but not Toll-like receptor 4 , is induced by LPS and inflammatory cytokines in mouse macrophages. J Immunol 2000;165:5767-5772.

110 Lin Y, Lee H, Berg AH, Lisanti MP, Shapiro L, Scherer PE: The lipopolysaccharide-activated toll-like receptor (TLR)-4 induces synthesis of the closely related receptor TLR-2 in adipocytes. J Biol Chem 2000;275: 24255-24263.

111 Visintin A, Mazzoni A, Spitzer JH, Wyllie DH, Dower SK, Segal DM: Regulation of Toll-like receptors in human monocytes and dendritic cells. J Immunol 2001;166: 249-255.
112 Perera PY, Mayadas TN, Takeuchi O, Akira S, Zaks-Zilberman M, Goyert SM, Vogel $\mathrm{SN}$ : CD11b/CD18 acts in concert with CD14 and Toll-like receptor (TLR) 4 to elicit full lipopolysaccharide and taxol-inducible gene expression. J Immunol 2001;166:574581.

113 Monick MM, Powers L, Butler N, Yarovinsky T, Hunninghake GW: Interaction of matrix with integrin receptors is required for optimal LPS-induced MAP kinase activation. Am J Physiol Lung Cell Mol Physiol 2002;283:L390-L402.

114 Wang JH, Manning BJ, Wu QD, Blankson S, Bouchier-Hayes D, Redmond HP: Endotoxin/lipopolysaccharide activates NFkappa B and enhances tumor cell adhesion and invasion through a beta 1 integrin-dependent mechanism. J Immunol 2003;170: 795-804.

115 Papi A, Stanciu LA, Papadopoulos NG, Teran LM, Holgate ST, Johnston SL: Rhinovirus infection induces major histocompatibility complex class I and costimulatory molecule upregulation on respiratory epithelial cells. J Infect Dis 2000;181:17801784.

116 Debbabi H, Ghosh S, Kamath AB, Alt J, Demello DE, Dunsmore S, Behar SM: Primary type II alveolar epithelial cells present microbial antigens to antigen-specific CD4+ T cells. Am J Physiol Lung Cell Mol Physiol 2005;289:L274-L279.

117 Henderson WR Jr, Chi EY, Albert RK, Chu SJ, Lamm WJ, Rochon Y, Jonas M, Christie PE, Harlan JM: Blockade of CD49d (alpha4 integrin) on intrapulmonary but not circulating leukocytes inhibits airway inflammation and hyperresponsiveness in a mouse model of asthma. J Clin Invest 1997; 100:3083-3092.

118 Burns JA, Issekutz TB, Yagita H, Issekutz AC: The alpha 4 beta 1 (very late antigen (VLA)-4, CD49d/CD29) and alpha 5 beta 1 (VLA-5, CD49e/CD29) integrins mediate beta $2(\mathrm{CD} 11 / \mathrm{CD} 18)$ integrin-independent neutrophil recruitment to endotoxin-induced lung inflammation. J Immunol 2001; 166:4644-4649.

119 Abraham WM, Ahmed A, Serebriakov I, Carmillo AN, Ferrant J, de Fougerolles AR, Garber EA, Gotwals PJ, Koteliansky VE, Taylor F, Lobb RR: A monoclonal antibody to alphalbeta1 blocks antigen-induced airway responses in sheep. Am J Respir Crit Care Med 2004;169:97-104.

120 Hogg N, Bates PA: Genetic analysis of integrin function in man: LAD-1 and other syndromes. Matrix Biol 2000;19:211-222.

121 Isberg RR, Barnes P: Subversion of integrins by enteropathogenic Yersinia. J Cell Sci 2001;114:21-28.

122 Hopkins PA, Sriskandan S: Mammalian Toll-like receptors: to immunity and beyond. Clin Exp Immunol 2005; 140:395407. 
123 Fallon PG, Allen RL, Rich T: Primitive Toll signalling: bugs, flies, worms and man. Trends Immunol 2001;22:63-66.

124 Fan J, Frey RS, Malik AB: TLR4 signaling induces TLR2 expression in endothelial cells via neutrophil NADPH oxidase. J Clin Invest 2003;112:1234-1243.

125 Nilsen N, Nonstad U, Khan N, Knetter CF, Akira S, Sundan A, Espevik T, Lien E: Lipopolysaccharide and double-stranded RNA up-regulate toll-like receptor 2 independently of myeloid differentiation factor 88 . J Biol Chem 2004;279:39727-39735.

126 Beutler E, Gelbart T, West C: Synergy between TLR2 and TLR4: a safety mechanism. Blood Cells Mol Dis 2001;27:728730 .
127 Sato S, Nomura F, Kawai T, Takeuchi O, Muhlradt PF, Takeda K, Akira S: Synergy and cross-tolerance between toll-like receptor (TLR) 2- and TLR4-mediated signaling pathways. J Immunol 2000; 165: 7096-7101.

128 Whitmore MM, DeVeer MJ, Edling A, Oates RK, Simons B, Lindner D, Williams BR: Synergistic activation of innate immunity by double-stranded RNA and $\mathrm{CpG}$ DNA promotes enhanced antitumor activity. Cancer Res 2004;64:5850-5860.

129 van Heel DA, Ghosh S, Butler M, Hunt K, Foxwell BM, Mengin-Lecreulx D, Playford RJ: Synergistic enhancement of Toll-like receptor responses by NOD1 activation. Eur J Immunol 2005;35:2471-2476.
130 Tada H, Aiba S, Shibata K, Ohteki T, Takada $\mathrm{H}$ : Synergistic effect of Nod1 and Nod2 agonists with toll-like receptor agonists on human dendritic cells to generate interleukin-12 and T helper type 1 cells. Infect Immun 2005;73:7967-7976.

131 Rogers NC, Slack EC, Edwards AD, Nolte MA, Schulz O, Schweighoffer E, Williams DL, Gordon S, Tybulewicz VL, Brown GD, Reis e Sousa C: Syk-dependent cytokine induction by Dectin-1 reveals a novel pattern recognition pathway for $\mathrm{C}$ type lectins. Immunity 2005;22:507-517.

32 Taylor PR, Tsoni SV, Willment JA, Dennehy KM, Rosas M, Findon H, Haynes K, Steele C, Botto M, Gordon S, Brown GD: Dectin-1 is required for beta-glucan recognition and control of fungal infection. Nat Immunol 2007;8:31-38. 